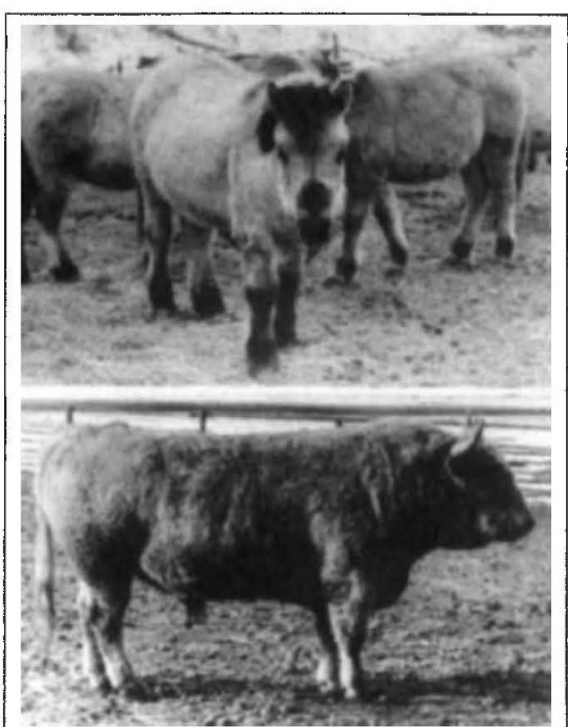

The Novosibirsk geneticists are concentrating on the practical. Like preserving a herd of the ragged Yakut horse (top) and the Yakut cattle, resistant to frost and able to pick up the grass from under a layer of snow.

stations). The institute has latterly been using the techniques of molecular biology in the pursuit of its long-standing interest in gene regulation, wherein lies a more controversial tale.

How to domesticate the silver fox? A successful answer to this problem would have an obvious interest for the fur industry, which would prefer not to have to go hunting for these animals (and people are in any case worried about their survival). This line of thought prompted, 30 years ago, the still-continuing study of the process of domestication, which in turn has provoked the study of the genetics of the inheritance of animal aggressiveness and other behavioural traits.

To vistors from the West, these sound like Lamarckian exercises, but Shumny insists that there is no heresy in his conviction that it is possible to breed for traits such as aggressiveness and its opposites that mark out readiness for domestication. On the contrary, the study founded by Balyaev is said to show that the phenotypic changes accompanying domestication do not imply genomic reconstruction, but changes in the pattern of gene regulation, possibly causing the activation of silent genes or increasing the natural mutation rate. Intracellular influences, such as hormone levels, might serve to switch from one pattern of gene regulation to another.

Why, for an institute that claims to publish a fifth of its research papers in Western journals, has this material made so little impact outside the Soviet Union, or even Novosibirsk? Shumny and his colleagues did not jump at the notion that a review article in Nature might do the trick, but one would be welcome, while the refereeing process would be instructive for all concerned.

New departures

\title{
Starting out afresh in Siberia
}

IF being sent to Siberia is a misfortune, electing to go there must be a folly. But there are compensations, which explains why Dr Mikhail Grachev has taken the job as director of the Institute of Limnology at Irkutsk, on the Trans-Siberian Railway at the point at which the Siberian plain joins the mountainous region to the east.

Grachev has persuaded a score of colleagues, some of them at odds with their institute directors, to migrate east with him from Novosibirsk. Last month, he was living with ten of his new colleagues in a communal apartment, but hoping to have been given somewhere more permanent by now. Meanwhile, there are people in Novosibirsk packing their equipment in preparation for slipping into newly emptied beds.

The venture is important both as a test of the flexibility of the administrative structure that seems normally to inhibit the movement of people and as a test of glasnost in the narrow sense of interdisciplinary communications.

Irkutsk is not everybody's vision of Siberia, but a typical small Soviet city, with close on a million people, a university and the regulation Intourist hotel. Across the river from the old city is the akademgorodok (for "academic town"). This is where Grachev has settled at the institute of limnology. His brief, from the Siberian Division of the academy, is to make Lake Baikal the centrepiece of a cross-disciplinary research programme whose guiding principle is merely that the lake is extremely interesting. One longterm but incidental effect may be to sharpen the tone of Irkutsk's akademgorodok. In a city five hours ahead of Moscow and an hour behind Tokyo, it is a little like being asked in eighteenthcentury England to go and manage a colony in the New World: remoteness gives you independence, but also great responsibility.

Grachev, a soft-spoken but sharptongued man in his early forties, seems undismayed. An ecologist himself, Grachev has already gathered together a hard core of people who know about aquatic microorganisms, and has also formed a group of dedicated instrumentbuilders whose techniques may be applied to the study of Lake Baikal while providing grist for the mill of the always-nascent Soviet instrumentation industry.

One of his colleagues is Sergei Kuzmin, who has developed a liquid chromatography instrument, with a built-in doublebeam spectrophotometer which, he claims, requires less of the expensive purified solvent than similar machines available in the West. (The group is still resentful that the Swedish company LKB decided some years ago not to market the device internationally, noting that more than 1,000 copies of it have so far been manufactured for domestic use.)

Another zealous designer is working with a Leningrad institute on the development of a novel and sensitive molecular mass spectrometer (intended to be used for baseline measurements of the present contamination of Lake Baikal) as well as a group skilled at synthesizing oligonucleotides (see pp. 802 and 792 respectively). Partly because of the second of these developments, Grachev is looking for molecular biologists keen to apply their techniques to the evolutionary history of the species of Lake Baikal.

There are more radical ideas in the air. Grachev takes it as a given that Lake Baikal is too interesting to be exclusively a Soviet preserve. He wants to make it international. Ingeniously following the glasnost principle that "what is not forbidden must be allowable", he has concluded that there is nothing in the academy's rules to prevent him employing specialists from abroad (a point confirmed in Moscow by a slightly startled $\mathrm{Mr}$ I.A. Timofeev, a member of the academy's Department of Foreign Relations). To begin with, Grachev would like to find a biologist from the West willing to make an "excursion" to Baikal and then perhaps to send a research student prepared to live on "our rubles" and to "share our life"

Part of the hidden agenda is to make a stronger link with science in the West. (Interested readers should write directly to Dr Grachev at the Institute of Limnology, Far Eastern Branch, Siberian Division of the Academy of Sciences of the USSR, Irkutsk, but Nature would also like to know of any expressions of interest.

More immediately, Grachev has designs on the University of Irkutsk. "We should be doing more teaching", he says. In due course, no doubt, that will be the case. But it will be an uphill task. So, too, will be that of sustaining the spirits of the new team through the hardships of the winter now beginning.

Grachev's adventure, like those of many other Siberian pioneers, is an intellectual risk. Distance from Moscow may offer opportunity, but also the chance of being forgotten. Grachev believes he has the personal backing of Academician Valentin Koptyug, president of the Siberian Division, but to the extent that his success will turn on people's willingness to break with the traditions of immobility and many other backward conventions of Soviet science, even those who have no inclination to join the venture might send him and his colleagues a greeting at the coming winter solstice. 